\title{
IAMJ
}

INTERNATIONAL

AYURVEDIC

MEDICAL JOURNAL

\section{AYURVEDIC MANAGEMENT OF PERICHONDRITIS (VIDARIKA) - A CASE STUDY}

\author{
Snehapriya P. R ${ }^{1}$, Venkatesh B. $A^{2}$
}

PG Scholar ${ }^{1}$, Professor ${ }^{2}$

Dept. of Shalakya Tantra, Sri Kalabyraveshwara Swamy Ayurvedic Medical College Hospital \& Research Centre, Bangalore, Karnataka, India

Corresponding Author: snehapriyapramachandran@gmail.com

https://doi.org/10.46607/iamj6108102020

(Published online: October 2020)

Open Access

(C) International Ayurvedic Medical Journal, India 2020

Article Received: 01/10/2020 - Peer Reviewed: 03/10/2020 - Accepted for Publication: 04/10/2020

(A) Check for updates

\section{ABSTRACT}

Ayurveda being the science of life deals with the detailed description \& Management of all disease conditions. In our Samhitha the importance is given to all system equally. Ayurveda is mainly divided into study of 8 branches which includes Urdwajatrugata as one of the important branches. This science includes all the ailments \& Description about the Vyadhis related to Urdwajatru i.e. structures above neck which include Netra (Eye), Karna (Ear), Nasa (Nose), Mukha (Oral) and Shiro (Head). Karna being the organ for hearing is given more importance in every Samhithas. Karna is divided into 3 parts Bahya Karna (Outer ear), Madhya Karna (Middle ear), Abhyanthara Karna (Inner ear). Here, in this article an attempt is made to discuss a case of Vidarika which is one among Karnapaliroga.

Keywords: Karnapali, Vidarika, Perichondritis

\section{INTRODUCTION}

Indriya, which is not seen with naked eye, along with 'Shashkuli' is called Shrotra i.e. Karna'. Charakacharya have mentioned that
Karnendriyaadhistana exhibits 2 parts namely Karna Shashkuli and Karnaputraka ${ }^{2}$, where Chakrapani have commented on this as Karnashaskuli is Karnagata 
Avarta and Karnaputraka is Bahyakarna. As per the modern medicine the external ear exhibits many elevations and depressions on lateral surface of pinna which resemble the whirl, and this is to be taken as Avarta. So Karnashaskuli is that part of Karna which resembles Avarta ${ }^{3}$. Astanga Hridayakara ${ }^{4}$ and Astanga Sangrahakara ${ }^{5}$ mentions Karnaroga as 25 in no, in which15 are Karnagata Roga and 10 are Karna Paligataroga. One among the Karnapaligata Roga is Vidarika which is been discussed here in this case.

\section{Aim and Objectives}

To evaluate the efficacy of Ayurvedic medicines in the management of Vidarika.

\section{Presenting Concern}

A male patient of age 49 years (OPD NO-G5840) who is not a known case of Diabetes mellitus and Hypertension, was apparently healthy 15 years back. In 2005 one day he noticed with pain in the right ear with mild swelling and this was associated with itching sensation. The size of swelling was increasing day by day and one day this got ruptured leaving a wound. Watery discharge was seen first and later he noticed serous discharge from the wound occasionally and mild redness still persisted over the pinna. Gradually there was pulling type of pain in the pinna and head occasionally. So, he consulted an allopathic hospital at Chitradurga for the same and was prescribed with medication. After using those medication there was reduction of these symptoms. The pain got reduced after medication all the symptoms got relieved subsequently. In between 2005-2018 he had 4 episodes of same complaint which he noticed that it appears only in the right ear and on having medication it used to get reduced. In 2019 February he developed with pulling type of pain in the pinna and right side of head with mild swelling in the pinna associated with Redness and itching of right pinna since 2-3 days, discharge (serous discharge). Hence, he consulted Shalakya OPD of
SKAMC. His personality was average built; body weight was $77 \mathrm{~kg}$ and belonging to middle class socioeconomic status. Occupationally, he was a businessman. No significant family history and personal history identified. His vitals were within normal limits. On general examination, there was no pallor, icterus, clubbing of nails, oedema or lymphadenopathy noted. No CVS, CNS abnormalities noted on through examination.

\section{Ear Examination-}

Examination of External Ear

Shape and size of Pinna-Normal

Microtia \& Macrotia- absent

Colour and texture- Reddish, tenderness present (Rt ear)

Oedematous(Rt ear)

Wound present on anterior part of right ear (Rt ear)

Serous discharge seen (Rt ear)

Left ear- Normal

Examination of middle ear, Tympanic membrane, Tuning fork test- Normal

\section{Case Concept and Line of Treatment}

Perichondritis results from infection secondary to lacerations, Haematoma or Surgical incisions. It can also result from extension of infection from diffuse ottitis externa or a furuncle of meatus. Pseudomonas and mixed flora are the pathogens responsible. Initial symptoms are red, hot and painful pinna which feels stiff. Later abscess may form between the cartilage and perichondrium with necrosis of cartilage. In Ayurveda this can be correlated to Vidarika which is one among Karnapaligata Roga specially mentioned by Acharya Vagbhata, he mentions its signs and symptoms as painful, static, skin coloured swelling seen in Karnashaskuli (here its seen in Anti helix region) due to the vitiation of Tridosha. He also mentions it as an Asadya Vyadhi but also quotes that Amavasta can be taken as Sadhya and Pakwavasta as Asadhya. 


\begin{tabular}{|c|c|c|}
\hline Date & Treatment Given & Result \\
\hline 13/02/2019 & $\begin{array}{l}\text { Stanika Abhyanga With Moorchitha Tila Taila } \\
\text { Patrapinda Sweda } \\
\text { Guggulu Dhooma } \\
\text { Karna Pichu With Jatyadi Taila } \\
\text { Karna Pali Prakshalana With Panchavalkala Kwatha } \\
\text { Trayodashanga Guggulu } 2 \text { TID }\end{array}$ & $\begin{array}{l}\text { Pulling type of pain in right pinna } \\
\text { Pain right side of head } \\
\text { Swelling in right pinna } \\
\text { Mild discharge } \\
\text { Redness and itching in right pinna }\end{array}$ \\
\hline 14/02/2019 & $\begin{array}{l}\text { Stanika Abhyanga With Moorchitha Tila Taila } \\
\text { Patrapinda Sweda } \\
\text { Guggulu Dhooma } \\
\text { Karna Pichu With Jatyadi Taila } \\
\text { Karna Pali Prakshalana With Panchavalkala Kwatha } \\
\text { Trayodashanga Guggulu } 2 \text { TID }\end{array}$ & $\begin{array}{l}\text { Pulling type of pain in right pinna persisted } \\
\text { Pain right side of head slight relief } \\
\text { Swelling in right pinna } \\
\text { Mild discharge } \\
\text { Redness and itching in right pinna }\end{array}$ \\
\hline $15 / 02 / 2019$ & $\begin{array}{l}\text { Stanika Abhyanga With Moorchitha Tila Taila } \\
\text { Patrapinda Sweda } \\
\text { Guggulu Dhooma } \\
\text { Karna Pichu With Jatyadi Taila } \\
\text { Karna Pali Prakshalana With Panchavalkala Kwatha } \\
\text { Trayodashanga Guggulu } 2 \text { TID }\end{array}$ & $\begin{array}{l}\text { Pulling type of pain in right pinna } \\
\text { Pain right side of head reduced } \\
\text { Swelling in right pinna reduced } \\
\text { Mild discharge } \\
\text { Redness and itching in right pinna-slight relief }\end{array}$ \\
\hline $16 / 02 / 2019$ & $\begin{array}{l}\text { Stanika Abhyanga With Moorchitha Tila Taila } \\
\text { Patrapinda Sweda } \\
\text { Guggulu Dhooma } \\
\text { Trayodashanga Guggulu } 2 \text { TID }\end{array}$ & $\begin{array}{l}\text { Pulling type of pain in right pinna persisted but } \\
\text { about } 70 \% \text { reduced } \\
\text { Pain right side of head reduced } \\
\text { Swelling in right pinna reduced } \\
\text { Discharge reduced } \\
\text { Redness and itching in right pinna-reduced }\end{array}$ \\
\hline 17/02/2019 & $\begin{array}{l}\text { Stanika Abhyanga With Moorchitha Tila Taila } \\
\text { Patrapinda Sweda } \\
\text { Guggulu Dhooma } \\
\text { Trayodashanga Guggulu } 2 \text { TID }\end{array}$ & $\begin{array}{l}\text { Pulling type of pain in right pinna persisted but } \\
\text { about } 40-60 \% \\
\text { Pain right side of head Absent } \\
\text { Swelling in right pinna reduced } \\
\text { No discharge } \\
\text { Redness and itching in right pinna-absent }\end{array}$ \\
\hline 18/02/2019 & $\begin{array}{l}\text { Stanika Abhyanga With Moorchitha Tila Taila } \\
\text { Patrapinda Sweda } \\
\text { Guggulu Dhooma } \\
\text { Trayodashanga Guggulu } 2 \text { TID }\end{array}$ & $\begin{array}{l}\text { Pulling type of pain in right pinna persisted but } \\
\text { about } 20-30 \%\end{array}$ \\
\hline 19/02/2019 & $\begin{array}{l}\text { Stanika Abhyanga With Moorchitha Tila Taila } \\
\text { Patrapinda Sweda } \\
\text { Guggulu Dhooma } \\
\text { Trayodashanga Guggulu } 2 \text { TID }\end{array}$ & Pulling type of pain in right pinna- absent \\
\hline
\end{tabular}

Result: Significant changes in signs and symptoms were noticed before treatment and after treatment with short course duration of 7 days. Patient felt good response after 2 nd day of intake of treatment. On the last day of commencement of treatment -7 th day; he was happy and was free from the condition. On follow up the sign and symptoms didn't reoccur and till date there were no such complaints reported by the patient.

\section{DISCUSSION}

In this study a combination of internal medicine along with external therapeutic procedure is been given simultaneously. So, a combination all these medicines 
gave the best results. Here Abhayanga was done to the pinna and nearby areas, Snehana is a measure adopted to bring snigdata in our body. Vidarika is a tridoshaja vyadhi and as the patient was also complaining of pulling type of pain in pinna, with the Snehana and swedana effect this complains got reduced. For snehana moorchitha tila thaila was used, Tila Taila has properties like Snehana, Sandhaniya, Rasayana, and also other properties. Whereas swedana was done by patrapinda sweda which has many vatakaphahara drugs as ingredients in making the potli used for patrapinda sweda. Mainly Nirgundi, Eranda, Arka, Shigru, Agnimanta etc. leaves are used here, these possess Kapha-Vata Shamaka, Rasayana, analgesic and antiinflammatory properties, which helps in reduction of the swelling. Guggulu dhooma was given after the Snehana and Swedana. Guggulu has vatahara property. Guggulu is beneficial in cleansing and healing of wounds and to reduce oedema due to its anti inflammatory and antiseptic properties. Here Jatyadi thaila karna pichu is kept on the pinna for 3 days and acquired result was obtained as Jatyadi Thaila possess properties like Shothahara, vedanastapana and Ropaka the wound healed, and discharge stopped. Whereas Panchavalkala Kwatha as name suggests Kashaya made up of Panchavalkala that is a group of bark of five trees Vata, Ashwatta, Plaksha, Parisha, Udumbara is found to be very effective in vrana Shodana and Ropana property. Trayodashanga Guggulu which is a combination of 13 drugs and Guggulu as main ingredients acts as Shoolaprashamana, Tridosha Shamaka, Shothahara and Vranahara action. Thus, by the combination of all these drugs acted well in this case and improvement with best results was seen with no reoccurrence till date.

\section{CONCLUSION}

Vidarika was told in classics is an Asadya Vyadhi but acharya has also mentioned that it can be treated and by these treatments we can prove that an attempt can be made for treating cases like Vidarika or perichondritis. Sthanika Abhyanga and Patrapinda sweda helps in released pain, relaxation of the muscles, activated the local metabolic process, increased local blood flow, and thus increased the absorption of Snehathrough the skin. After administration of Swedana, it might produce a hypoanalgesic effect by diverted stimuli. Guggulu has yogvahi property which makes it useful in this condition.

Acharya Charaka and Vagbhata has mentioned in our Samhitha that Karnapoorana can should be done as daily routine to keep away from ear diseases, simple Tila Taila can also be used for this purpose.

\section{REFERENCES}

1. Madhavakara; Madhava nidana: Shastri sri Sudarshan, Chaukambha Sanskrit sansthan. Varanasi,2000. pp.472.

2. Acharya Yadavji Trikamji. Caraka Samhitha by Agnivesha Revised by Caraka and Dridabala with Ayurveda Dipika Commentary of ChakrapaniDatta: Varanasi: Chaukambha Oriantalia; Reprint 2015. Shareerasthana

3. Prof. Dr. Narayan J.Vidwansa. Shiro-Karna-Nasa \& Mukha-Dantaroga Vidnyan(A textbook of E.N.T and Oro-dental Diseases-A Comprehensive Study): Shalakya-2:Pune:Vimal Vision Publication; ${ }^{\text {nd }}$ edition; Reprint 2018pp.65

4. Vaidya Bhishak Acharya Harisastri Paradakara. Astanga Hrudayamcomposed by Vagbhata with the commentaries (Sarvangasundara) of Arunadatta and (Ayurveda rasayana) of Hemadri collated by late Dr Anna Moreswara Kunte and Krsna Ramachandra Sastri Navare: $10^{\text {th }}$ ed. Varanasi: Chaukambha Oriantalia; Reprint 2014

5. Acharya Vagbhata, Ashtanga Sangraha, translated by Prof KR Srikanthamurthy, Vol 3,9th edition 2005, Chaukhamba Orientalia, uttarastana, 21.

\section{Source of Support: Nil \\ Conflict of Interest: None Declared}

How to cite this URL: Snehapriya P. R \& Venkatesh B. A: Ayurvedic Management Of Perichondritis (Vidarika) - A Case Study. International Ayurvedic Medical Journal \{online\} 2020 \{cited October, 2020\} Available from: http://www.iamj.in/posts/images/upload/4930_4933.pdf 